Actas del Seminario Internacional Destinos Turísticos Inteligentes:

nuevos horizontes en la investigación y gestión del turismo

Universidad de Alicante, 26 y 27 de octubre de 2017

\title{
Smart island tourism and strategic marketing: the case of the island of El Hierro
}

\author{
Carmen Díaz Dominguez \\ Mercedes Revilla Hernández \\ Agustín Santana Talavera \\ Eduardo Parra López
}

Universidad de La Laguna. Instituto Universitario de Ciencias Políticas y Sociales

\begin{abstract}
Tourism and technology grow quickly generating behaviors that force challenges and dynamic decision-making. Tourist destinations have to deal with a complex environment that makes their competitive position dependent on Information and Communications Technology (ICT). As all citizens can be connected, better informed and engaged, the concept of Smart Destination needs to integrate tourism planning and territory services for the visitor. This will influence the motivation of tourists when they choose their holiday destination. The aim of this work is to create a theoretical and practical conceptualization of Smart Island, using the case of El Hierro (Canary Islands, Spain), one of the first Smart Island in the world.
\end{abstract}

Keywords: Smart destination; Smart tourism, Smart Cities; Smart Islands, Technology; Sustainable; Renewable Energy.

\section{Introduction}

Tourism is an important part of the service sector. Developments in new technologies reinforce organizational and structural innovations. During the last years, the effort in tourism has concentrated in the exploitation of Information and Communication Technologies (ICTs) (Buhalis, 2003). More and more people live in cities and more and more people travel to enjoy it. Werthner (2003), suggest that «ICT could contributes in terms of generating value-added experiences for tourists, while also improving efficiency and supporting process automation for the related organizations». Concepts like technology, communication, innovation or quality come to mind when we 
Actas del Seminario Internacional Destinos Turísticos Inteligentes:

nuevos horizontes en la investigación y gestión del turismo

Universidad de Alicante, 26 y 27 de octubre de 2017

think in «Smart». Nowadays concepts such as Smart Destinations, Smart Cities and Smart Islands are being studied and applied in the territory improve the quality of life for residents and tourists and to encourage responsible and sustainable management of the territories that promote human development criteria (UNDP) (Malik, 2014)

In island contexts, technologies (ICTs) provide both get data making the intercom and relations between mainland territories and insular areas, favoring progress and resilience processes. Being tourism a mainstay of island economies, bringing smartness into Tourism destinations requires dynamically interconnecting stakeholders through a technological platform on wich information relating to tourism activities could be exchanged instantly. Zheng Xiang (2014) who writes that smart Tourism destinations take advantage of Technology embedded environments; responsive processes at micro and macro levels; end-user devices in multiple touch-points; and engaged stakeholders that use the platform dynamically as a neural system supports this view. This ultimate aim is to utilize the system to enhance tourism experience and improve the effectiveness of resource management towards maximizing both destination competitiveness and consumer satisfaction while also demonstrate sustainability over an extended timeframe (Boes, Buhalis and Amaranggana, 2014; Boes, Buhalis and Inversini, 2015)

This work takes as a case study the island of El Hierro, for being considered the first island Smart even without implementing an important part of the operational indicators defined and applied in Integral Revitalization Plan of Tourism of the island of El Hierro (PRITIEH 2013) conducted by the authors of this paper. The paper reviews conceptually the construct Smart City and its various applications (Smart destination, Smart Island). It was taken as a starting point to Cohen (2012) and the consequent development enhanced by European Smart City. While important areas of implementation Smart used, it was considered necessary to conduct a more thorough review of the literature, establishing a set of Smart factors applied to island ecosystems. It is from them that these factors proceeded to contrast with BRSmart program, leading to the definition of a set of 80 operational indicators and sensors 209 information. 
Actas del Seminario Internacional Destinos Turísticos Inteligentes:

nuevos horizontes en la investigación y gestión del turismo

Universidad de Alicante, 26 y 27 de octubre de 2017

\subsection{Highlights}

The overall objective has been to develop a theoretical framework that englobes the three concepts of Smart, Smart City, Smart Destination and Smart Island, later worked less compared to the previous two concepts.

1) The development of a methodology to Smart Islands that we have contrasted with El Hierro. The general interest of our methodology is that any island could place themselves to be a Smart Island. We have defined areas and smart indicators for verifying the implementation of Smart Island.

2) Resposible Management of islands ecosystems. The mechanism "Smart» is a tool to achieve this goal.

3) Application of philosophy «Smart» in island ecosystems (Unesco).

The ultimate goal is the management system and the approach of future scenarios to islands.

\section{Theoretical background}

\subsection{Smart City, Smart Destination and Smart Island}

The overlap between the production space and consumption space is logical in the tourism sector. Destination must be understood like a subsystem configured by spatial elements (land resources, infrastructures...), administrative and productive elements and for its complex interrelationships and the effects they produce (Timón, 2004).

The rapid increase of urban population worldwide has triggered intricate challenges for cities around the world. Thus, Information and Communications technology (ICT) enhance the tourist experience in cities. The concept of smart city was created from the necessity to seeking better management and more liveable cities that encourage sustainability information and the best experience of being a citizen. The development of very larger such as Beijing, New Delhi, London and São Paulo the drive to increase competitiveness by cities such Portland, San Francisco, Shanghai make Smarten essential for competing. From this first approach, the Smart destination concept emerges (Buhalis, 2014). Parallel to this, the concept of Smart Island is developed with the objective of enhancing the citizens' quality of life and its services efficiency, such as optimizing the use of energy and better traffic monitoring (Vicini et al. 2012). In the case of cities and municipalities, a 
Actas del Seminario Internacional Destinos Turísticos Inteligentes:

nuevos horizontes en la investigación y gestión del turismo

Universidad de Alicante, 26 y 27 de octubre de 2017

precedent issue is Agenda 21. Agenda 21 is the reference for the implementation of development sustainable in the territories.

ICT coordinate all activities and services, leading to connected, better informed and engaged citizens. Further, this infrastructure make cities more accessible and enjoyable for both residents and visitors through interactive service interconnecting all local organizations to provide real-time services and use data centrally for better coordination.

The interest about the concept of Smart City is growing. In Spain, since 2012 , cities began to organize themselves to share information and experiences as a way to learn from each other. This situation led to the creation of the Network of Smart Cities in Spain. Worldwide, many cities are putting in efforts to become smart cities underway, but each case is different. The municipal government adapt their improvement efforts to the specific needs of each city. In cities like Amsterdam and Malaga, energy companies have played a very important role. Other cases like Madrid and Stockholm, the starting points were aspects of public safety and traffic management. When think to become Smart, the success of the city, is not guaranteed. It is a long process, where multiple transformations occur. It is a change comprising initiatives in the areas of government, buildings, mobility, energy and environment and media services (Achaerandio, Curto, Bigliani, \& Gallotti, 2012) through different levels of maturity:

Level 1. Scattered. These cities are trying to improve one or more smart dimensions. It introduces, for example, intelligent transport systems and reduces energy consumption. At this level, smart initiatives are led by departmental structures as a series of isolated projects.

Level 2. Integrated. At this level of maturity, initiatives are better coordinated, try to exploit synergies and cities manage projects with a greater degree of collaboration. The total value provided by the initiative is greater than the sum of its parts.

Level 3. Connected. At this level, smart projects are integrated and managed by a team of specific government that include citizens and business plan. The cities that are connected get better social outcomes. (Achaerandio et al., 2012; Boes, Buhalis and Amaranggana, 2014; Boes, Buhalis and Inversini, 2015; Buhalis and Amaranggana, 2015)

Based on the definition given by the Final Report, «Smart Cities Report, Ranking of European cities, October 2007» developed by the Centre of Regional Science, Department of Geography and the Research Institute for 
Actas del Seminario Internacional Destinos Turísticos Inteligentes:

nuevos horizontes en la investigación y gestión del turismo

Universidad de Alicante, 26 y 27 de octubre de 2017

Housing, Urban and Mobility (OTB), a Smart City «is not very widely used yet in spatial planning literature or urban research, it is still possible to identify various aspects as a basis for further elaboration, from literature research the term is not used in a holistic way describing a city with certain attributes, but is used for various aspects which range from Smart City as an IT-district to a Smart City regarding the education (or smartness) of its inhabitants. In the following the various aspects will be summarized». When a Smart City experiences a development, this fact means that it is also positive to "create a value-added services both for its citizens and tourists as city visitors, such as access to real-time information on public transportation network» (Boes, K., Buhalis, D Aditya Amaranggana, 2014)

Cohen, B. (2012) suggest six dimensions to should be take into account in a Smart City. A Smart City is one city that uses information and communication technologies, not only for the transmission of information that is inherent to the functioning of the city and harmonious coexistence, but also for the use of physical, material resources, humans who allow their self-sustainability but, above all, to generate knowledge. Digital cities are therefore environments in which predominates artificial intelligence, behavior and anticipate needs, but especially where social practices are transformed (Casas, 2014). Cohen (2012) define six indicators for the Smart City:

- Smart Economy: By Smart economy, they mean e-business and e-commerce, increased productivity, ICT-enabled and advanced manufacturing and delivery of services, ICT-enabled innovation, as well as new products, new services and business models. It also establishes Smart clusters and eco-systems. Smart economy also entails local and global inter-connnectedness and international embeddedness with physical and virtual flows of goods, services and knowledge

- Smart People: e-skills, working in ICT-enabled working, having access to education and training, human resources and capacity management, within an inclusive society that improves creativity and fosters innovation.

- Smart Governance: the European Union means joined up within-city and across-city governance, including services and interactions that link and, where relevant, integrate public, private, civil and European Community Organizations so the city can function efficiently and effectively as one organism. The main enabling tool to achieve this 
Actas del Seminario Internacional Destinos Turísticos Inteligentes:

nuevos horizontes en la investigación y gestión del turismo

Universidad de Alicante, 26 y 27 de octubre de 2017

is ICT enabled by Smart processes and interoperability and fuelled by data. International, national and hinterland links are also important (beyond the city), given that a Smart City could be described as quintessentially a globally networked hub. Smart objectives include transparency and open data by using ICT and e-government in participatory decision-making and co-created e-services.

- Smart Mobility: ICT supported and integrated transport and logistics systems. For example, sustainable, safe and interconnected transportation systems can encompass trams, buses, trains, metros, cars, cycles and pedestrians in situations using one modes of transport.

- Smart Environment: Smart energy including renewables, ICT-enabled energy grids, metering, pollution control and monitoring, renovation of buildings and amenities, Green buildings, Green urban planning, as well as resource use efficiency, re-use and resource substitution which serves the above goals. Urban services such as Street lighting, waste management, drainage systems, and water resource systems that are monitored to evaluate the system, reduce pollution and improve water quality are also good examples.

- Smart Living: ICT-enabled life styles, behavior and consumption. Smart Living is also linked to high levels of social cohesion and social capital. Smart living is also healthy and safe living in a culturally vibrant city with diverse cultural facilities, and incorporates good quality housing and accommodation.

The Smart Destination concept emerges from the development of Smart Cities (Boes et. al., 2014). While the Smart City concept is focused on citizens, i.e. not contain temporal visitor, the approach of Smart Destination includes this part of population i.e. tourists and travelers (Lamsfus \& Alzua-Sorzabal, 2013). A Smart destination is a territory where «the investments in human capital and traditional transport and modern ICT communication infrastructure meet the social, cultural, economic, leisure and personal needs of visitors. Visitors are short-term citizens of a Smart City (Lamsfus \& Alzua-Sorzabal, 2013). In accordance with Shaffers et. al. (2011), "the first task that destinations must address in becoming smart is to create a rich environment of broadband networks that support intelligent applications. The second step is to provide full coverage of the characteristic tourism products and services to improve and make the competitiveness of a destination 
Actas del Seminario Internacional Destinos Turísticos Inteligentes:

nuevos horizontes en la investigación y gestión del turismo

Universidad de Alicante, 26 y 27 de octubre de 2017

sustainable in time». There are three forms of ICT, which are crucial for setting up Smart Tourism destinations (Boes et al., 2014). The Cloud Computing services are with the objective to reduce fixed costs and shift them into variable costs based on the necessities (Etro, 2009). Secondly, ICT support smart destinations by providing information and analysis as well as automation and control (Chui et al. 2010). For instance, the chips embedded to entrance ticket allow tourism service providers to track tourist's locations and their consumption behavior real time so that location-based advertising could be executed (Lin 2011). Third place is situated the End-User Internet Service System, refers to number of applications at various levels supported by combination of Cloud Computing and ICT.

\subsection{Smart Islands}

An island is an ecologically isolated self-contained territory (dependent on many occasions, outside energy, communications and inputs commodity) with a principal and network of smaller cities and villages. In many islands, in recent decades, tourism has formed the main source of income. The need to reduce long-term dependency, optimizing the use of resources and trying to ensure the quality of life of people, promotes the Smart motion applied to the island territories.

A generally accepted definition in the current literature of Smart Island is lacking. Nevertheless, the Smilegov project's members have provided a new definition in the "Islands strategy communication paper, 2013». They point out «Smart Island is an insular area that creates sustainable local economic development and high quality of life by excelling in multiple key areas of sustainability; such as the economy, mobility, energy, environment, human capital and excellence in governance». This definition does not move away from the smart destinations and smart cities meaning. The current literature about this research line shows that the concept of smart islands can be perfectly explained by taking into account the concept of other terms before mentioned, which are the base of the theory.

A smart island destination (SEGITTUR (2013), is an innovative touristic destination, consolidated with a technological infrastructure, which assure the sustainable development in a touristic territory, as well as it is accessible for everybody, it makes easy the interaction with the visitors and it increases the user's experience. In addition, citizens in smart islands have their quality of life improved and local economies, as well. The main responsible factor 
Actas del Seminario Internacional Destinos Turísticos Inteligentes:

nuevos horizontes en la investigación y gestión del turismo

Universidad de Alicante, 26 y 27 de octubre de 2017

is the investments in sustainable solutions in a number of essential sectors of the local economy, such as energy, water, transport, tourism, agriculture, fisheries and waste management. To get good outcomes it is important to manage a Multilevel Governance system and processes in order to improve the cooperation and the decision-making process across all levels of government.

ICT is the basic infrastructure of a smart island, used not only in cyber space, but also as communicating elements of physical infrastructure, transmitting real-time data on an island's status by way of sensors and processors applied within real-world infrastructure. However, all this technological infrastructure should have a proper connectivity that enables to run them (Romero, 2012).

In this regard, it is important for the government supported by various stakeholders to maintain adequate network coverage within the destination to avoid gap between commercially dense area and rural area (Buhalis, Amaranggana, 2014)

The implementation of strategic actions in islands is different from other destinations. The size, geographical location and economic, social and cultural factors play an important role in the ability of an island to plan sustainable programs and actions. The members of the Smilegov Project have proposed to classify the islands in two main categories:

- Pioneer or leading islands, which already have experience in implementing sustainable actions and projects and have the capacity and the political will to continue undergoing significant technology and organizational transformation and continue leading by example.

- Ambitious or willing to learn islands, that have the ambition and the political will to continue on the path of acquiring expertise and the capacity to improve their living condition and continue on the path of sustainability.

A smart island certification is also proposed, whose program is to be developed and communicated to all the islands that participate in the initiative. Thus, islands that fulfil the basic parameters will be entitled to a Smart Island certification.

Applying the Smart Tourism Destinations theory of Gretzel (2011), Smart Islands are not free from political influence, as it opens certain social options and closes others. In this regard, measuring the performance of islands as 
Actas del Seminario Internacional Destinos Turísticos Inteligentes:

nuevos horizontes en la investigación y gestión del turismo

Universidad de Alicante, 26 y 27 de octubre de 2017

tourism destinations by attributing a higher score to specific settings could be used as a political tool considering that charts are politician's favorite to justify their political rationales. Further, the danger of using ranking as benchmark for measuring success is to subsequently develop policies based on a single model to be applicable everywhere with limited local adaptation (McCann 2011). It is necessary to point out that there is only little room for the technologically illiterate and the poor within destinations.

\subsection{Smart Governance in island destinations}

Creating Smart Tourism Islands requires the engagement of community participation and public and private entities. Thus, E-governance is defined by UNESCO as the ability to governance, through electronic infrastructure. This new type of governance facilitates the process of dissemination of effective information. This process is fast and transparent to the public and other agencies, to develop effective administrative activities by the government (Rodríguez et al., 2011). Smart Governance is related to the aspect of transparency within governance system through modernization of city administration by supporting data openness and public involvement (Cohen, 2012).

Table 1: Smart Tourism destinations characteristics

\begin{tabular}{|l|l|}
\hline \multicolumn{1}{|c|}{ Stakeholders } & \multicolumn{1}{c|}{ Characteristics of outcome } \\
\hline $\begin{array}{l}\text { Tourism } \\
\text { organizations }\end{array}$ & $\begin{array}{l}\text { - Function as smart hub that coordinates all relevant information and } \\
\text { makes it easily accessible for users to access real-time information. }\end{array}$ \\
\hline Governments & $\begin{array}{l}\text { - Digitization of core business processes } \\
\text { - Optimize their energy use } \\
\text { - Engage with local communities, tourists and government in } \\
\text { co-creating tourism experience }\end{array}$ \\
\hline $\begin{array}{l}\text { Local } \\
\text { residents/ } \\
\text { local } \\
\text { communities }\end{array}$ & $\begin{array}{l}\text { - Organizational agility, speed decision making and responsive to } \\
\text { customers' needs based on just-in-time insights. }\end{array}$ \\
\hline Tourists & $\begin{array}{l}\text { - Precision targeting and personalized service } \\
\text { - Information governance that support data openness } \\
\text { - Regulate data privacy. }\end{array}$ \\
\hline
\end{tabular}


Actas del Seminario Internacional Destinos Turísticos Inteligentes: nuevos horizontes en la investigación y gestión del turismo

Universidad de Alicante, 26 y 27 de octubre de 2017

\begin{tabular}{|l|l|}
\hline Environment & - Establish Public-Private Partnership \\
- Constantly connected \\
- Sufficiently creative and empowered \\
- Technology savvy \\
- Citizen journalism \\
- Actively involved in developing smart heritage/ e-Culture \\
- Well-connected and well-informed \\
- Active critics and buzz marketers \\
- Demand highly personalized service \\
- Engaged both socially and technologically \\
- Dynamically discuss through social media \\
- Co-create experience \\
- Contribute to content \\
- Utilize end-user devices in multiple touch-points \\
- Interconnected through Internet of Things \\
- Presence of cloud computing services \\
- Innovation ecosystem \\
- Sensor networks throughout the environment \\
- Combine digital information and social contexts which will augment \\
- geophysical reality
\end{tabular}

Source: Personal compilation based on Buhalis \& Amaranggana, 2014. Smart Tourism Destinations, Xiang, Z., Tussyadiah, I., (eds) Information and Communication Technologies in Tourism 2014, pp.560-561.

In order to get a strong cohesion between real and virtual components of a destination it is important to take into account the crucial role that is played by the governance entities. This new dynamic comprises not only political participation, but also services for citizens as well as the functioning of administration. A good governance as an aspect of a smart island is often referred to the usage of new channels of communication for the citizens, for instance e-governance or e-democracy. The final report «Smart Cities Report, Ranking of European cities», October 2007, suggests the performance indicators that belong to smart governance. These indicators are used to take care with the outcomes. This Pls are: Participation in decision-making; Public and social services; Transparent Governance. In other words, it is important to promote the PPPP's action (Public, Private and People Partnership).

Table 1 illustrates the five principal stakeholders in a Smart island and the smart management. 
Actas del Seminario Internacional Destinos Turísticos Inteligentes:

nuevos horizontes en la investigación y gestión del turismo

Universidad de Alicante, 26 y 27 de octubre de 2017

\section{Methodology}

We have used the case study as a research method. This study sought to ascertain, from ethnographic fieldwork (qualitative research) and the document review, to what extent is it possible to consider The prototype Smart Hierro Island, Presented as has-been. This fieldwork is framed in the Comprehensive Revitalization Plan Tourist Island of El Hierro in the Canary Islands Government (PRITIEH 2013) by the authors of this article. We have worked in two lines: a) With the Smart Theories and b) with the European Smart Cities indicators (www.smart-cities.eu/index. php?cid=01\&ver=3). Finally we have created an Observatory of Smart Island.

For this we have considered a set of indicators to express in the literature, as a result of the analysis of the different strategies of development of cities and destinations.

From the review of literature on the conceptual progression from Smart City and Smart Destination has tried to concentrate and reduce the number of indicators, defining three groups of 12 key indicators (Smart Gov; Smart Tech, Smart Experience), from which a control shaft which affect wider energy efficiency is developed, mobility... with the goal of define the concept of «Smart Island».

This study sought to ascertain, from ethnographic fieldwork (qualitative research) and the document review, to what extent is it possible to consider El Hierro a prototype Smart Island, as has been presented. For this we have considered a set of indicators to express in the literature, as a result of the analysis of the different strategies of development of cities and destinations. Second, we proceeded to verification of international indicators based on European Smart Cities (TU-Vienna University of Technology Department of Spatial Planning).

\section{Factors of Social Character (Smart Gov)}

1) The investments in human social capital and traditional transport and modern ICT communication infrastructure meet the social, cultural, economic, leisure and personal needs of visitors (Lamsfus \& Alzua-Sorzabal, 2013) and citizens (Ayuntamiento de Santander, 2014) 
Actas del Seminario Internacional Destinos Turísticos Inteligentes:

nuevos horizontes en la investigación y gestión del turismo

Universidad de Alicante, 26 y 27 de octubre de 2017

2) Have to integrate tourism suppliers at both micro and macro level criming to ensure that benefit from this sector is well distributed to local society (Buhalis. D, 2014)

3) Internet access in libraries and schools and cultural centers (Tomás Casado, 2011)

4) E-Government: on-line processing of individual negotiations with the Public Administration (Tomás Casado, 2011), promoting transparency in decision-making (open data) (Cohen, B 2012)

Factors of Technological Character (Smart Tech)

1) Have technologies for data capture (include sensory networks), data transmission, storage and analysis (Tomás Casado, 2011)

2) Need to create a rich environment of broadband networks (can combine wireless technologies) that support intelligent applications and promotes communications (Lamsfus \& Alzua-Sorzabal, 2013; Tomás Casado, 2011)

3) Need a plataform to provide full coverage of the characteristic tourism products and services (Bonazountas, M. 2014; Buhalis. D, 2014; Lamsfus \& Alzua-Sorzabal, 2013; Tomás Casado, 2011; Wang, Li, \& Li, 2013)

4) Use their own data and data from third parties and offers it (Tomás Casado, 2011).

\section{Product service Factors (Smart experience)}

1) The co-creation of tourist experience entails not only experience customization by tourist, but more importantly., the increasing involvement of Destination Marketing Organizations and other tourists «experience sharing» (Wang, Li, \& Li, 2013)

2) Effective oriented citizenship in providing administration services accessible through different channels (Ayuntamiento de Santander, 2014)

3) The SC/SD/SI should to improved management, promotes innovation and participation (Aznarez, L., 2014; Tomás Casado, 2011) 
Actas del Seminario Internacional Destinos Turísticos Inteligentes:

nuevos horizontes en la investigación y gestión del turismo

Universidad de Alicante, 26 y 27 de octubre de 2017

4) Must offer its inhabitants and visitors ICT-based services that promote the mobility, tourism, entertainment, weather, health, environment, etc (Aznarez, L. 2014)

The detailed development of these 12 indicators lead to an approach of operational control as the European Smart Cities. The European Smart Cities explain a standardization and aggregation to compare the different indicators. The indicators that they apply are the same indicators from Cohen, B (2012), Smart Governance, Smart Economy, Smart Mobility, Smart Environment, Smart People and Smart Living. "This method transforms all indicator values into standardized values with an average 0 and a standard deviation 1 . This method has the advantages to consider the heterogeneity within groups and maintain its metric information. Furthermore a high sensitivity towards changes is achieved» (Giffinger et al., 2014), (table 2).

Three major areas to be used in a Smart Island: Smart Gob, Smart and Smart Tech Experience. Each of the areas contains four indicators based on the literature. The Observatory of Smart Island, a work that is part of the Biosphere Reserves, Biosphere MAB Smart and joined the theory of Cohen (2012) with an expansion of specific indicators and tools to apply the same, extends the scoreboard.

From Cohen (2012) the European Smart City has developed a series of factors that they take into account in determining the extent to which a city is smart or not. (see table 2).

Table.2. Criteria to be a Smart Island

\begin{tabular}{|l|l|l|}
\hline \multicolumn{1}{|c|}{ Smart Gov } & \multicolumn{1}{|c|}{ Smart Tech } & \multicolumn{1}{c|}{ Smart experience } \\
\hline $\begin{array}{l}\text { 1. The government } \\
\text { investments cover the } \\
\text { visitors'needs }\end{array}$ & $\begin{array}{l}\text { 1. Technology for data } \\
\text { management }\end{array}$ & $\begin{array}{l}\text { 1. Tourism experience } \\
\text { exchange }\end{array}$ \\
\hline $\begin{array}{l}\text { 2. Local societies benefit } \\
\text { from tourism suppliers }\end{array}$ & $\begin{array}{l}\text { 2. Broadband networks } \\
\text { infrastructure }\end{array}$ & 2. Corporate Citizenship \\
\hline 3. Internet facilities & $\begin{array}{l}\text { 3. Tourism products and } \\
\text { services platform } \\
\text { (http://elhierro.travel/) }\end{array}$ & $\begin{array}{l}\text { 3. Improved Smart } \\
\text { Management in innovation } \\
\text { and participation }\end{array}$ \\
\hline 4. E-Goverment & 4. Sharing Data & $\begin{array}{l}\text { 4 ICT services for Smart } \\
\text { experience }\end{array}$ \\
\hline
\end{tabular}

Source: own compilation based on bibliography. 
Actas del Seminario Internacional Destinos Turísticos Inteligentes:

nuevos horizontes en la investigación y gestión del turismo

Universidad de Alicante, 26 y 27 de octubre de 2017

For the development of the field's criteria have been treated indicators Biosphere Reserve in the UNESCO Man and Biosphere (MAB) program. They have initiated the operationalization of the indicators through its observatories. This program proposes an interdisciplinary research agenda and capacity building to improve the relationship of people with their environment globally. Use their network of Biosphere Reserves as a vehicle to share knowledge, do research and monitoring, education and training, and participatory decision-making.

Through MAB all actors involved in the fate acquire a commitment to promote the use of resources enabling sustainable. To do scientific, environmental, social and developmental skills are used to obtain a broader understanding of the environment. This program combines the natural sciences, social sciences, economics and education in order to improve the quality of life of human beings. On the other hand, the commitment to science and scientists to the development of sound policies from the point of view of biodiversity and natural resources is another objective of this program. The biosphere reserves are sites established by countries and recognized by the "Man and Biosphere. MAB, promote sustainable development based on local community efforts and support of science. These places are seeking a harmony between biological diversity and cultural to economic and social development, using the relationship between people and nature. They are territories that are known worldwide and where tests are performed to demonstrate innovative approaches to sustainable development at local and international levels.

The main functions of a biosphere reserve are:

a) Promoting economic, cultural and social development at the local level, maintaining natural resources so they can continue being used by other generations;

b) Maintain the diversity of landscapes, ecosystems, species and cultural heritage;

c) Contribute to the knowledge by supporting education, training, scientific research and exchange of information between people, technicians and researchers.

Inserted in the Biosphere Reserve, it is the BRSmart. This initiative under the slogan "Think globally, act locally," this is intended to establish a place to provide data for decision-making and provide the participation of 
Actas del Seminario Internacional Destinos Turísticos Inteligentes:

nuevos horizontes en la investigación y gestión del turismo

Universidad de Alicante, 26 y 27 de octubre de 2017

society in matters concerned with the environment. The initiative of the biosphere Smart is making the most of new information technologies (ICTs) to strengthen the pact for sustainable future and the transition to green economies based on knowledge, in a scenario of low $\mathrm{CO} 2$ emissions in the Reserves Biosphere. This platform has georeferenced information of Biosphere Reserves have the possibility in this same platform to access a broad level of details (water cycle, waste management, fauna, flora, biodiversity, climate...). It is an adaptation to the urban future in Biosphere Reserves and World Heritage cities.

Table 3: Indicators by European Smart City

\begin{tabular}{|l|l|l|}
\hline \multicolumn{1}{|c|}{ Smart Governance } & \multicolumn{1}{c|}{ Smart Mobility } & \multicolumn{1}{c|}{ Smart Environment } \\
\hline $\begin{array}{l}\text { - Participation public life } \\
\text { - Public and social services } \\
\text {-Transparent governance }\end{array}$ & $\begin{array}{l}\text { - Local accessibility } \\
\text { - (Intern-) nacional } \\
\text { accessibility } \\
\text { - Availability of IT } \\
\text { Infraestructure } \\
\text { - Sustainability of the } \\
\text { transport system }\end{array}$ & $\begin{array}{l}\text { - Environmental condition } \\
\text { - Air qualiy (no pollution) } \\
\text { - Ecological awareness }\end{array}$ \\
\hline \multicolumn{1}{|c|}{ Smart Living } & \multicolumn{1}{|c|}{ Smart Economy } & \multicolumn{1}{c|}{ Smart People } \\
\hline $\begin{array}{l}\text { - Cultural facilities } \\
\text { - Health conditions } \\
\text { - Individual security } \\
\begin{array}{l}\text { Education facilities } \\
\text {-Touristic attractiveness } \\
\text {-Economic welfare }\end{array}\end{array}$ & $\begin{array}{l}\text {-Innovative spirit } \\
\text {-Entrepreneurship } \\
\text {-Economic image \& } \\
\text { trademarks } \\
\text {-Flexibility of labour market } \\
\text {-International } \\
\text { embeddedness }\end{array}$ & $\begin{array}{l}\text {-Level of qualification } \\
\text {-Lifeong learning } \\
\text {-Ethnic plurality } \\
\text { Open-mindedness }\end{array}$ \\
\hline
\end{tabular}

Source: Personal compilation based on European Smart Cities (www.smart-cities.eu/index. php?cid=01\&ver=3) (TU-Vienna University of Technology Department of Spatial Planning)

In Biosphere SMART platform, there are only three islands that run under the digital system and BR are two islands in the Canary archipelago, El Hierro and Fuerteventura, in Spain and Island Prince Island in the Democratic Republic of Sao Tome and Principe.

Although, El Hierro has been chosen for this study because the following Reasons: 
Actas del Seminario Internacional Destinos Turísticos Inteligentes:

nuevos horizontes en la investigación y gestión del turismo

Universidad de Alicante, 26 y 27 de octubre de 2017

1) One of the initiatives of the Smart Biosphere Reserve has been to create a partnership between Canary Island BR Network, OSCG, Fuerteventura, Santana BR, Canary Islands Goverment- ICT, Principe Island Regional Government, Spanish MAB National Committee, Portuguese MAB National Committee, University of La Laguna, UNESCO Center of the Canary Islands, SBI (Observatory sustainability of Spain), REN21, INTERRA among others. Therefore, it has been an important consideration when selecting the case study factor.

2) El Hierro Island is a Biosphere Reserve.

3) Taking into account that El Hierro is a Biosphere Reserve, it has Already Implemented strategies and policies for technology implementation Positioned that have it as a global model for sustainable island, «Ecoisla».

4) As one of the first island Smart, it can be a global benchmark for other islands who want to get that indication.

\section{Case of study. El Hierro (Canary Islands)}

The island of El Hierro is situated in the Atlantic Ocean in the Canary Islands $\left(27 . .^{\circ} 45^{\prime} \mathrm{N} 18 .^{\circ} 00^{\prime} \mathrm{O}\right)$. It is the southernmost of all islands. For many centuries, it was considered the end of the world. Even today, there is a feeling of the end of the world. It is an island away from everything intact in many areas of the island. El Hierro lives mainly on agriculture, small livestock. The main industry is cheese, wine, fisheries and trade. The entire island was declared by UNESCO Biosphere Reserve (2000), by the ecological and biological value of the island. The tourism comes as an alternative to the crisis of these bases (Romero, 2012). The current situation of tourism in the island of El Hierro, before committed and marked by the seasonality of some very specific products such as diving and summer, has been seriously aggravated by communicative volcanic crisis management and connectivity, ie the possibility to book transportation, shopping and reach the island (Santana Talavera et al., 2013). El Hierro lives one seismic-volcanic crisis accompanied by an economic crisis and the disappearance of the main source of income (tourism) occurs.

El Hierro has tried to establish itself in recent decades as a sustainable island and integrally related to this objective has managed to become the first island in the world smart. El Hierro, has become one of the First World Islands that offers Free WiFi. It should highlight the green character of this 
Actas del Seminario Internacional Destinos Turísticos Inteligentes: nuevos horizontes en la investigación y gestión del turismo

Universidad de Alicante, 26 y 27 de octubre de 2017

initiative, in which has been necessary to alter the Natural Environment of the island, and almost the $80 \%$ of its territory is protected. In addition, this project has involved not only a Strong bet On The Renewable Energy and Sustainability but also a great help to revitalize the island in After Suffering from a volcanic eruption in 2011 and Subsequent numerous earthquakes.

In the Strategic Plan of 2020 designed by the European Comission (2013), Canary Islands are wanted to be consolidated as cultural, economic, relationship and cooperation referent of the Atlantic, building on their valuable geostrategic situation between America, Africa and Europe, which makes it a privileged tri-continental bridge, as well as their experience, knowhow, excellent quality of life and the unique environmental conditions.

To strengthen the tourism sector they have identified different areas to develop, where El Hierro is achieving some objectives as a Green island. In fact this island is named as a natural laboratory, where it is possible to promote pumped-storage hydroelectric plant projects.

In these plan, the objectives that are set to get a Smart Leadership in Tourism are, on the one hand, to improve the competitiveness and productivity of the Canary Islands tourist product, and on the other hand, to act as a vehicle for product diversification.

\subsection{El Hierro starts to became a Smart Island}

The Spain's Ministry of Industry decides to launch a program of special performances on the island of El Hierro throughout 2012 to try to get mitigate the negative effects on the economic situation of the island due to the volcano's eruption.

The program seeks to agree a number of units, the ministry companies, including own State Society for Innovation Management and tourism technologies (Segittur, 2013). SE launches this plan around 5 items:

- Support to the island in everything by covering financing needs

- Training and mentoring to explain to the islanders new business models

- Promoting international scale of the island, to publicize the island and spread out the reality of the island, whose main concept is that El Hierro is not dangerous.

- Enhancement of the enormous potential of the island from the point of view of its geological, geological phenomenon in its history. 
Actas del Seminario Internacional Destinos Turísticos Inteligentes:

nuevos horizontes en la investigación y gestión del turismo

Universidad de Alicante, 26 y 27 de octubre de 2017

- Developing El Hierro as an intelligent island.

Segittur's team has developed a variety of technological infrastructures that enable to connect different sensors on the island. These sensors recover and share regularly interesting information to tourists. The platforms custom services are also created to bid the tourists needs.

They also think about working with pure technology, environmental and energy issues. The Smart strategy is created based on three core factors: Pure technology, Enviromental and Energetical issues.

1) The first one is based on the ICT, the connectivity and information contents provisions to tourists that are doing activities on the island. They mean that these smart technologies will provide information to tourist depending on what they are doing or where they are.

2) Energy and energy efficiency. El Hierro has launched a hydro-wind power plant, which is called "Gorona del Viento». This power plant generates electricity from generating trade winds on the island. It generates enough electricity to be self-sufficient thanks to that wind power. However, the electricity generation from the generators is very interesting but very discontinuous because when there is no wind, the mills stop working. To deal with this problem, a hydrowind power station has been created. This power station connects the mills with a hydroelectric plant in which the force of the wind turbines pump water from a below Water Tank to a Top Water Tank. Regarding that, it stores energy by pumping the water up. In addition, thanks to these energy solutions the citizens get drinkable water from a desalination base which is situated near the sea.

This energy also contributes to promote the sustainable mobility such as the use of electric cars. In fact, there are already electric cars in El Hierro due to this initiative.

3) Alongside this plan, segittur has taken advantage of the «Gorona del Viento" project to enhance the infrastructure such as the implementation of WIFI and WIMAX connectivity along the entire island. Thus, El Hierro has become to a free-Wi-Fi Island and it let the visitors to be permanently connected and share the information they want to share.

4) They are also planning to develop an online platform that offers information about air temperature, rainfall, water temperature. They 
Actas del Seminario Internacional Destinos Turísticos Inteligentes:

nuevos horizontes en la investigación y gestión del turismo

Universidad de Alicante, 26 y 27 de octubre de 2017

plan to develop this idea to be shared through WIFI and WIMAX antennas by stakeholders (tourists, entrepreneurial and citizens). Thus, the tourist, enterprises and citizens relate each other and create a network structure. Each person that will connects to this network will provide value added to the other network's members.

5) Apps like «El Hierro te sigue» was born from the idea of creating the free WIFI connectivity. With this app, you can interpret a landscape while you are walking, or you can find information about different landscapes, hiking trails, etc...

Internally, tourism management of the island has tried to develop various Strategic Plans Tourism and territorial development, but their actions are shattered by a series of factors among which, without being exhaustive, lack of investment, no consideration of the various trends in target markets, the excessive their goals, supply shortages and lack of consensus, inclusion and business formalization.

\subsection{Problems / Key elements related to Governance}

The identification of key stakeholders that belong to the island of El Hierro, lead us to group them into the following structure:

Tourism organization and governments

- Cabildo de el Hierro: The intervention of the insular corporation spans much of the business of the island.

- Local Councils: El Hierro is composed of three municipal corporations; Council of Valverde, Council of La Frontera and Council of El Pinar. All three have a remarkable role in consolidating and promoting local employment.

- Entities related to the primary sector: The Cooperative Merca Hierro S.L. groups Cooperative Sea-Pescarestinga, Cooperative Society of "Campo Frontera" and Livestock Cooperative. The existence of Mercahierro has been important in promoting delicacies projected at the head of the equity offering of El Hierro.

- Associations: El Hierro-Rural: It comprises a set of traditional accommodation representative of the architecture of the island are all cottages of the original iron the eighteenth, nineteenth and early 
Actas del Seminario Internacional Destinos Turísticos Inteligentes:

nuevos horizontes en la investigación y gestión del turismo

Universidad de Alicante, 26 y 27 de octubre de 2017

twentieth centuries, which have recently been renovated following the guidelines of. old masters of the island and within the parameters established by the Law of Rural Tourism in the Canaries, which are legally established. Following the traditional style. (Santana Talavera et al., 2013).

Figure 1. El Hierro Stakeholders Maps.

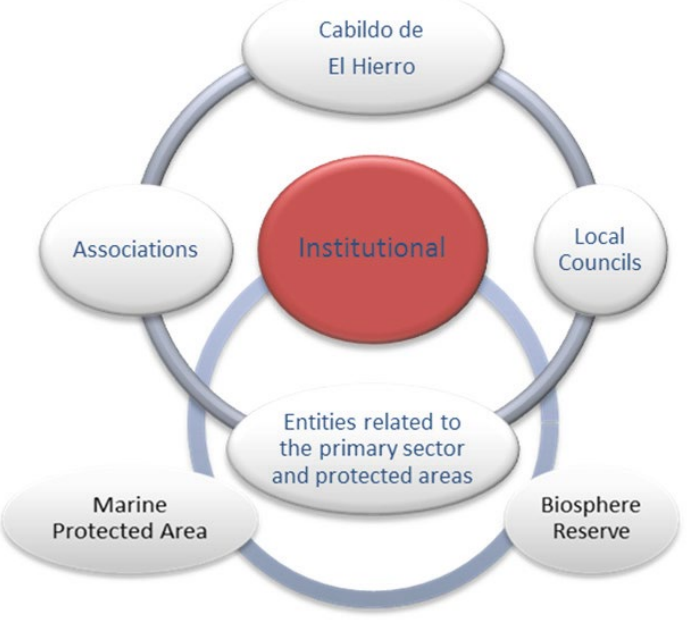

Source: Personal compilation based on fieldwork.

Local residents/local communities and environment

- Marine Protected Area: This Marine Protected Area was declared in 1996. It is attached to the micro destination of La Restinga, has managed project at the head of the national diving destinations.

- Biosphere Reserve: UNESCO declared the island of El Hierro Biosphere Reserve on 22 January 2000. The cataloging of the various areas of the island within the reserve is the same as that contained in the Island Plan, which does not involve restrictions additional development or construction. Under the recognition «umbrella» of the Biosphere Reserve, has driven the Insular Waste Plan, Insular Hydrological Plan, Rural Tourism, Agriculture and Farming, the Associations, the Leader actions on rural areas, and has supported the 
Actas del Seminario Internacional Destinos Turísticos Inteligentes:

nuevos horizontes en la investigación y gestión del turismo

Universidad de Alicante, 26 y 27 de octubre de 2017

project $100 \%$ Renewable Energy for the island of El Hierro Canary Islands Government.

Set of touristic enterprises

Touristic islands, as El Hierro, are isolative territories, productive places and innovative ones that are potencially very environmentally friendly, fulfilling almost every aspect of desirability for the future. On the other hand, a fast and intensive arrival of new citizens and visitors present with very challenges in the present and in the immediate future. Thus, there is a high probability of pollution and limited access to resources. That is why it is important to count with Islands' city councils coordination in order to deal with such challenges. Therefore, the importance of management and the role of information and communication technologies in the implementation of ideas are of crucial significance. The relevance of the Smart Islands concept is providing for the needs and thus attracting people of various generations is of utmost economic relevance, since these people are perceived to be the developers of new economic potentials and opportunities and the competition for hosting members of these highly mobile generations is rapidly increasing among destinations over the world (Harrison \& Donnelly, 2011).

According with Zheng Xiang and lis Tussyadiah (2014) the stakeholders of a smart destination are tourism organizations, government, local residents/local communities, tourists and environment. Taking into account that is relevant to analyze the stakeholder of a destination we have analyzed $\mathrm{EI}$ Hierro's stakeholders.

In the E-governance context, nationally, it has been implemented a strategic plan to promote the E-government through the AVANZA2 plan 20112015. The Avanza Plan has four axes to perform: digital citizenship (quality of life), digital economy (competitiveness), digital context (productivity), and education and digital public services (social welfare). This plan looks for initiatives that are more responsive to end users' needs and demands. ICT take-up will increase when users are convinced about their utility, safety and when they experience the benefits realized directly. There are several opportunities for doing so:

- Local governments have a direct line with citizens. In fact, e-government efforts have been focused on the back-office, but the Avanza local programmes applications and activities that interface with 
Actas del Seminario Internacional Destinos Turísticos Inteligentes:

nuevos horizontes en la investigación y gestión del turismo

Universidad de Alicante, 26 y 27 de octubre de 2017

citizens and SMEs (training, informative sessions, e-inclusion initiatives, social services, teleworking, culture, traffic, etc.)

- The plan could consider strengthening efforts towards increasing trust in the public sector through the use of ICTs. For instance through «Open government» initiatives for promoting transparency and re-use of public data.

- Proposals for Plan Avanza 2 suggest that such an approach will be launched to promote the usage and maximise the benefits of eID cards, but efforts could be extended to other major e-government initiatives as well.

- Law 11/2007 of electronic access of citizens to public services: gives the citizens the right to communicate with the Public Administrations by electronic means, with an Availability of $24 \times 7 \times 365$.

- The plan has launched the development of an updated database on services of the SI and electronic communications services in Spain.

Currently, the implementation of this plan and the transparency, Open Data and e-accountability are being developed and used by citizens incipiently. In the Open data case, there are already some platforms where access to open data. El Hierro has its own url, but it is possible to find open data in the Canary islands Government's platform.

Table 4. List of Open Data platforms in Canary islands' Governance

\begin{tabular}{|l|l|}
\hline \multicolumn{1}{|c|}{ Name } & \multicolumn{1}{c|}{ URL } \\
\hline Cabildo Insular de La Palma & http://www.opendatalapalma.es/ \\
\hline Ayuntamiento de Arona & http://datos.arona.org/ \\
\hline Tenerife data & http://www.tenerifedata.com/ \\
\hline Open Data Canarias & http://opendatacanarias.es/ \\
\hline Gobierno de Canarias Open Data & http://opendata.gobiernodecanarias.org/ \\
\hline
\end{tabular}

Source: Personal compilation.

\section{Results}

Given the limited supply of literature concerning the Smart Islands compared to what is published on Smart Cities and Smart Destinations, it was necessary to base part of the theory applied to Smart Islands in what had already 
Actas del Seminario Internacional Destinos Turísticos Inteligentes:

nuevos horizontes en la investigación y gestión del turismo

Universidad de Alicante, 26 y 27 de octubre de 2017

been written on Smart Cities. On the hand, the results were obtained after application of theories of Smart City to Smart Island; in this case, the specific results of the island of El Hierro (first island Smart). Secondly the results provided by the authors of this article having defined three areas, and merging them with the theory of Cohen (2012) and the UNESCO MAB program are presented, creating an Observatory for a repository Smart Islands of indicators to measure the intelligence of a territory.

\subsection{Results obtained by theories Smart City}

Applying the methodology to the island of El Hierro, the results after using the theories of Smart City to Smart Island are those shown in the following tables.

In the table 5 has been used the theory of Cohen (2012) and Smart City application by the GSMA. Have been applied to the island of El Hierro to find out what efforts has carried out the island to become a Smart Island.

Table 5: Specific efforts of El Hierro to be a Smart Island

\begin{tabular}{|c|l|l|}
\hline \multicolumn{1}{|c|}{ Smart Governance } & \multicolumn{1}{|c|}{ Smart Mobility } & \multicolumn{1}{c|}{ Smart Environment } \\
\hline $\begin{array}{l}\text {-Plan Avanza 2 strategies. } \\
\text {-Public and social services: } \\
\text { Apps and Open Data. }\end{array}$ & $\begin{array}{l}\text {-Electric cars } \\
\text {-3 Charging stations } \\
\text {-26 WIFl's spots in the } \\
\text { entire island WIMAX } \\
\text { connectivity }\end{array}$ & $\begin{array}{l}\text {-Energy storage thanks to } \\
\text { the hydrowind power plant; } \\
\text { drinkable water }\end{array}$ \\
\hline Smart Living & \multicolumn{1}{|c|}{ Smart Economy } & \multicolumn{1}{c|}{ Smart People } \\
\hline & & $\begin{array}{l}\text {-Visitors permanently } \\
\text { connected }\end{array}$ \\
\hline
\end{tabular}

Own elaboration based on Cohen (2012) and Smart City Aplicattion por Guide to a Smart City (GSMA 2013)

Table 6, using European Smart Cities, has made an approach to analyze whether El Hierro meets each of the indicators arises. In each of the blocks, it defined a number of features that should play a Smart Island. Having analyzed the island of El Hierro in these areas the results are summarized in the table. They have been used symbols to know if you have achieved (+) if it is in the process of doing (+/-) or if you have not yet made it to establish the criteria that are specified. 
Actas del Seminario Internacional Destinos Turísticos Inteligentes:

nuevos horizontes en la investigación y gestión del turismo

Universidad de Alicante, 26 y 27 de octubre de 2017

Taking account table 7 it is analyzed the degree of compliance Criteria European Smart Cities. It can be observed El Hierro complies with the majority criterias of Smart Environment and Smart Economy. The Island has to strengthen the rest of Smart Criterias.

Table 6. Degree of Compliance Criteria European Smart Cities (TU Vienna University Department of Planning Technology)

\begin{tabular}{|c|c|c|c|c|c|c|}
\hline $\begin{array}{c}\text { Smart } \\
\text { Governance }\end{array}$ & Smart Mobility & $\begin{array}{c}\text { Smart } \\
\text { Environment }\end{array}$ & Smart Living & Smart Economy & \multicolumn{2}{|l|}{ Smart People } \\
\hline $\begin{array}{l}\text { Participation } \\
\text { public life }\end{array}$ & +/- Local accessibility & $\begin{array}{l}+ \text { Environmental } \\
\text { condition }\end{array}$ & + Cultural facilities & $+/-$ Innovative spirit & $\begin{array}{l}+ \text { Level of } \\
\quad \text { qualification }\end{array}$ & - \\
\hline $\begin{array}{l}\text { Public and social } \\
\text { services }\end{array}$ & $\begin{array}{l}+ \text { (Intern-) nacional } \\
\text { accessibility }\end{array}$ & $\begin{array}{l}\text { - Air qualiy (no } \\
\text { pollution) }\end{array}$ & + Health conditions & +/- Entrepreneurship & + Lifeong learning & + \\
\hline \multirow[t]{4}{*}{$\begin{array}{l}\text { Transparent } \\
\text { governance }\end{array}$} & $\begin{array}{l}\text { +/- Availability of IT } \\
\text { Infraestructure }\end{array}$ & $\begin{array}{r}+ \text { Ecological } \\
\text { awareness }\end{array}$ & + Individual security & $\begin{aligned}+ & \text { Economic image \& } \\
& \text { trademarks }\end{aligned}$ & + Ethnic plurality & + \\
\hline & $\begin{array}{l}\text { Sustainability } \\
\text { of the transport } \\
\text { system }\end{array}$ & $+/-$ & $\begin{array}{l}\text { Education } \\
\text { facilities }\end{array}$ & $\begin{array}{l}+/- \text { Flexibility of labour } \\
\text { market }\end{array}$ & $\begin{array}{l}+ \text { Open- } \\
\text { mindedness }\end{array}$ & $+/-$ \\
\hline & & & $\begin{array}{l}\text { Touristic } \\
\text { attractiveness }\end{array}$ & $\begin{array}{ll}+ & \text { International } \\
& \text { embeddedness }\end{array}$ & $+/-$ & \\
\hline & & & Economic welfare & $+/-$ & & \\
\hline
\end{tabular}

Source: Personal compilation based on European Smart Cities (www.smart-cities.eu/index. php?cid=01\&ver=3) (TU-Vienna University of Technology Department of Spatial Planning).

\subsection{Observatory of Smart Island}

Taking account table 7 it is analyzed the degree of compliance Criteria European Smart Cities. It can be observed El Hierro complies with the majority criterias of Smart Environment and Smart Economy. The Island has to strengthen the rest of Smart Criterias. In table number 5 is analyzed the criteria specifically to El Hierro, this table examines Smart Government, Smart Tech and Smart experience. The island offers very good internet facilities with its 26 WIFI spots, another strong point is its improved Smart Management in innovation and participation with its energy storage.

We have defined three big areas where there are four indicators in each of them. We explain the the degree of compliance with the study criteria to be a Smart Island (table 7).

Take into account the indicators to be a Smart City defined by the European Smart Cities; we applied these indicators in El Hierro to be a Smart Island (table 7). 
Actas del Seminario Internacional Destinos Turísticos Inteligentes: nuevos horizontes en la investigación y gestión del turismo

Universidad de Alicante, 26 y 27 de octubre de 2017

Table. 8. Degree of compliance with the study criteria to El Hierro as a Smart Island

\begin{tabular}{|c|c|c|c|c|c|}
\hline Smart Gov & & Smart Tech & & Smart experience & \\
\hline $\begin{array}{l}\text { 1. The government } \\
\text { investments cover the } \\
\text { visitors'needs }\end{array}$ & + & $\begin{array}{l}\text { 1. Technology for data } \\
\text { management }\end{array}$ & & $\begin{array}{l}\text { 1. Tourism experience } \\
\text { exchange }\end{array}$ & $+/-$ \\
\hline $\begin{array}{l}\text { 2. Local societies benefit } \\
\text { from tourism suppliers }\end{array}$ & $+/-$ & $\begin{array}{l}\text { 2. Broadband } \\
\text { networks } \\
\text { infrastructure }\end{array}$ & & $\begin{array}{l}\text { 2. Corporate } \\
\text { Citizenship }\end{array}$ & $+/-$ \\
\hline 3. Internet facilities & + & $\begin{array}{l}\text { 3. Tourism products } \\
\text { and services platform } \\
\text { (http://elhierro. } \\
\text { travel/) }\end{array}$ & $+/-$ & $\begin{array}{l}\text { 3. Improved Smart } \\
\text { Management in } \\
\text { innovation and } \\
\text { participation }\end{array}$ & + \\
\hline 4. E-Goverment & & 4. Sharing Data & $+/-$ & $\begin{array}{l}4 \text { ICT services for } \\
\text { Smart experience }\end{array}$ & $+/-$ \\
\hline
\end{tabular}

Source: Personal compilation based on literature.

Figure 2 theoretical contribution to this article aims to explain is contemplated. Where three theoretical axes where indicators that have to be taken into account when setting when an island is Smart are determined. To explain this theoretical chart will be based on the general to the specific.

The first theoretical axis is enveloping the other two and corresponds with which this research group defined with theoretical basis, as Smart Tech, Smart Gob (within the theory of Cohen, B. (2012) would correspond to "Smart Governance») and Smart Experience (in theory Cohen, B. (2012) corresponds with «Smart Living»). Each of these three areas have been defined previously.

In the second theoretical axis indicators Cohen, B (2012), the authors define it as factors, and as already mentioned above, appear are those who have used «The European Smart Cities» to establish indicators Smart Cities and to be used in part to establish indicators of the Smart Islands. The factors that are within the three areas mentioned above are: Smart Environment, Smart People, Smart Economy and Smart Mobility.

Finally, the third axis that arises is part of Unesco's MAB (2012) sustainability indicators program, which in Spain have been working since 2005 by the Observatory of Sustainability in Spain (OSE). We used the indicators of the MAB program and reinserted in Cohen posed, B (2012). Each indicator 
Actas del Seminario Internacional Destinos Turísticos Inteligentes:

nuevos horizontes en la investigación y gestión del turismo

Universidad de Alicante, 26 y 27 de octubre de 2017

$M A B$, born about operational indicators are those that should test to see if an island is Smart.

However, the observatory has 209 direct (quantitative) and indirect sensors (qualitative) as the basic source. While the former refers figures provided by institutions and companies, the latter are obtained from fieldwork and surveys for this purpose. The data set must be weighted (weight indicator) as qualitative assessment contextualized (ethnographic) to suit the specific decision-making.

Figure 2: Observatory of a Smart Island

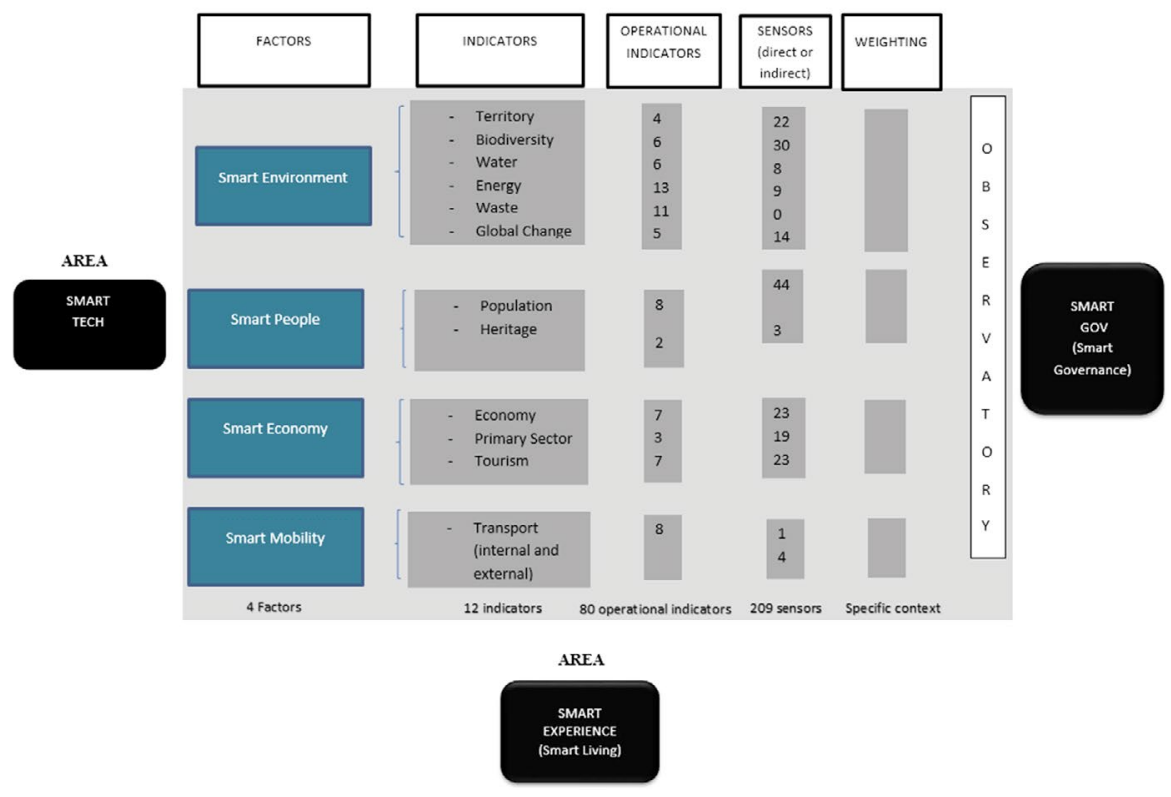

Source: Authors

\section{Discussion and limitations}

Once operational indicators panel defined, public-private cooperation is needed to feed the databases and technological platforms, this being one of the limitations related to the implementation of strategies island destination. 
Actas del Seminario Internacional Destinos Turísticos Inteligentes:

nuevos horizontes en la investigación y gestión del turismo

Universidad de Alicante, 26 y 27 de octubre de 2017

It is a problem of «cultural mental model» that being so users must opt for the open data for the structural system of the Smart Island manages to be efficient. This would involve transforming a model focused on stakeholders to another based on the shareholders.

The island of El Hierro has been marked by the double insularity, asylee of the major tourist circuits that socioeconomic and demographic drove the rest of the Canary Islands. These conditions of marginality, periphery, with low rate of land occupation without intensive exploitation, have led circumstances that could turn it into a laboratory for sustainability, planning and example for other territories. With own and external initiatives and economic momentum of the governments of the European Union, State Spanish and Canary Islands, have taken steps in environmental protection, mobility, energy and technological implementation, and some way to go in transparency and shared governance.

Considering the theory given by the report research ICT about the different level of maturity of a city, we can applied this theory to El Hierro and we can say that this island is situated in disperse level because the island is committed to improve one or more intelligent dimensions, for example by introducing intelligent transport systems and reducing energy consumption. At this level, smart initiatives are led by departmental structures as a series of isolated projects.

There is a lack of initiatives coordination. Therefore, information and communication technologies (ICT) are critical to increase the level of maturity. The information that is offered in digital platforms is opened. The opened information exists when the level of maturity of a Smart Island is dispersed. The city tries to offer its citizens and companies, different types of information through Internet portals. The information is generic and not adapted to different needs.

In the Smart Governance context, the situation of E-government management in Spain is in its infancy and it is virtually nonexistent in El Hierro. According to the principles of E-government initiatives, the Avanza 2 plan is being implemented, but they are still performing the initiatives incipiently. Even though there is a transparent government, accountability, open data and availability, the collaboration between stakeholders is limited. In other words, the efforts could be extended to other major e-government initiatives. 
Actas del Seminario Internacional Destinos Turísticos Inteligentes:

nuevos horizontes en la investigación y gestión del turismo

Universidad de Alicante, 26 y 27 de octubre de 2017

The democratic institutions are not adapted to large changes such as the ICT revolution and its people behaviour's mutations that have occurred (Sierra, 2014). There is no consensus on the content and scope of those changes. Changes are needed but there have not been a situation of consensus, even there is no knowledge of what should be the content thereof. To accommodate an active citizen that is critical to the current democracy.

Going to which perhaps is the most interesting part of this article, the observatory of a Smart Island, this group have thought in European Smart City. They have defined a Smary City Profile and it would be interesting to apply the observatory to define a Smart Island Profile too.

Overall, the Smart Island as a concept should be further analyzed and exemplified with multiple case studies. So far, the projection of Smart Destination / Smart City is being fruitful, but environmental constraints of an island territory, especially marked by connectivity in transport, demographic imperative containment and energy efficiency should make a specific development that may serve to control future sustainability strategies. This paper has tried to show how to construct a simplified set of criteria easily operationalized qualitatively to define a Smart island.

El Hierro like a Smart Island is a case of study that we have contrasted with our methodology to be a Smart Island. But it is important to consider that this is a path to long-term goals and always improved.

\section{References}

Achaerandio, R., Curto, J., Bigliani, R., \& Gallotti, G. (2012, Análisis de las ciudades inteligentes en españa 2012 - el viaje a la ciudad inteligente. IDC Analyze the Future, 1-24.

Ángela Sierra. Iberoamerican Congress of Public Innovation «Novagob 2014» https://vimeo.com/116745968

Arcos, A. (2012). Los proyectos Smartcity de Endesa. Retrieved from: http:// www.aec.es/c/document_library/get_file?uuid=c2af288b-8d2c-4474-b2ae667a9d3a09f0\&groupld $=10128$

Ayuntamiento de Santander. (2014). Santander smart city, plan director de innovación. Retrieved from http://portal.ayto-santander.es/documentos/plan_ director_innovacion.pdf

Aznarez, L. (3 ${ }^{\text {rd }}$ April, 2014). Deloitte. Introducción a las Smart Cities. Concepto de Smart Island. Oportunidades de Desarrollo Económico. [Powerpoint slides]. Retrieved from www.proyectoantares.com/portal/ponencias/2.pptx 
Actas del Seminario Internacional Destinos Turísticos Inteligentes:

nuevos horizontes en la investigación y gestión del turismo

Universidad de Alicante, 26 y 27 de octubre de 2017

Boes, K., Buhalis, D., and Inversini, A., 2015, Conceptualising Smart Tourism Destination Dimensions, in Tussyadiah, I., and Inversini, A., (eds), ENTER 2015 Proceedings, Lugano, Springer-Verlag, Wien, ISBN:9783319143422, pp. 391-404.

Buhalis, D., Amaranggana, A., 2014, Smart Tourism Destinations, Xiang, Z., Tussyadiah, I., (eds) Information and Communication Technologies in Tourism 2014, pp.553-564

Buhalis, D., Amaranggana, A., 2015, Smart Tourism Destinations Enhancing Tourism Experience through Personalisation of Services, in Tussyadiah, I., and Inversini, A., (eds), ENTER 2015 Proceedings, Lugano, Springer-Verlag, Wien, ISBN:9783319143422, pp.377-390

Chui, M., Löffler, M., \& Roberts, R. (2010). The Internet of things. McKinsey, 2, 1-9.

Cohen, B. (2012). Smart cities hub. Retrieved July 22, 2013, from http://smartcitieshub.com/2012/11/11/smart-cities-ranking-methodology/

Communication From the Commission. (2013). Europe 2020: Action Plan in the canary islands. Brussels: European Commission. Retrieved 10 January 2015 from: http://ec.europa.eu/regional_policy/activity/outermost/doc/plan_ action_strategique_eu2020_canarias_en.pdf

Crouch, D. \& Desforges, L. (2003). The sensuous in the tourist encounter. Tourist Studies, 3(1): 5-22.

Davis, F. D. (1993). User acceptance of information technology: system characteristics, user perceptions and behavioral impacts. International journal of man-machine studies, 38(3), 475-487.

Duran, C. (2013). Governance for the Tourism sector and its Measurement, UNWTO Statistics and TSA Issue Paper Series STSA/IP/2013/01 (Online), retrieved 29 December 2013 from http://statistics.unwto.org/en/content/papers

Etro, F. (2009). The economic impact of cloud computing on business creation, employment and output in Europe. Review Business and Economics, 54(2), 179-208.

Giffinger, R., Kramar, H. \& Strohmayer, F. (2014). European smart cities 3.0 (2014). Retrieved from http://www.smart-cities.eu/index.php?cid=-1\&ver=3

Gottschall, J. (2012). The Storytelling Animal: How Stories Make Us Human. Houghton Mifflin Harcourt Publishing Company

Government of the Canary Islands (2013). Europe 2020 action Plan in the Canary Islands. Retrieved from: http://ec.europa.eu/regional_policy/activity/outermost/doc/plan_action_strategique_eu2020_canarias_en.pdf

Gretzel, U., Fesenmaier, D.R. \& O'Leary, J.T. (2006). The transformation of consumer behaviour. In D. Buhalis \& C. Costa (Eds.), Tourism business frontiers: Consumers, products and industry, (pp. 9-18). Oxford:Elsevier.

Gretzel, U. \& Jamal, T. (2009). Conceptualizing the creative tourist class: Technology, mobility, and tourism experiences. Tourism Analysis, 14(4): 471-481. 
Actas del Seminario Internacional Destinos Turísticos Inteligentes:

nuevos horizontes en la investigación y gestión del turismo

Universidad de Alicante, 26 y 27 de octubre de 2017

Hancke, G. P., \& Hancke Jr, G. P. (2012). The role of advanced sensing in smart cities. Sensors, 13(1), 393-425.

Harrison, C., \& Donnelly, I. A. (2011). A theory of smart cities. Proceedings of the 55th Annual Meeting of the ISSS-2011, 55(1). Hull, UK.

Kickert, W. (1993). Complexity, governance and dynamics: Conceptual explorations of public network management. Modern Governance, 191-204.

Kooiman, J. (2005). Gobernar en gobernanza. La gobernanza hoy: 10 textos de referencia (). Madrid: INAP.

Kooiman, J. (2002). Governance. A social-political perspective. Participatory governance (pp. 71-96) Springer.

Lamsfus, C., \& Alzua-Sorzabal, A. (2013). Theoritical framework for a tourism internet of things: Smart destinations. tour GUNE Journal of Tourism and Human Mobility, 0.2, 1521.

Lin, Y. (2011). The application of the Internet of things in Hainan tourism scenic spot. Hainan: Seventh International Conference on Computational Intelligence and Security

Malik, K. (2014). Human development report 2014. Sustaining human progress: Reducing vulnerabilities and building resilience. new york. united development programme.

Mayntz, R. (2005). Nuevos desafíos de la teoría de la gobernanza. Madrid: INAP.

Mayntz, R. (1998). Nuevos retos para la teoría de la gobernanza.50 (The Robert Schuman Centre - Jean Monet Chair Papers,)

Neuhofer, B. (2014). The Technology Enhanced Tourist Experience. Information and Communication Technologies in Tourism 2014, 90.

Prats i Catalá, J. (2005). De la burocracia al Management, del Management a la Gobernanza, Las transformaciones de las Administraciones Públicas de nuestro tiempo. (Octubre ed.). Madrid: Instituto Nacional de Administración Pública.

Rhodes, R. A. W. (1997). Understanding governance: Policy networks, governance, reflexivity and accountability

Rodríguez, R. A., Giulianelli, D., Trigueros, A., Vera, P. M., \& Marko, I. (2011). Gobernabilidad Electrónica. In XVII Congreso Argentino de Ciencias de la Computación. Rose, F. (2011). The Art of Immersion - How the digital generation is remaking Hollywood, Madison Avenue, and the way we tell stories. W. W. Norton \& Company Santana, A. (2009). Antropología del turismo; analogías, encuentros y relaciones. São Paulo, Brasil: Aleph

Santana Talavera, A., Parra Lopez, E., De la Cruz Modino, Raquel, Melgar, S., Díaz Domínguez, C., \& Pascual, J. J. (2013). Plan de reactivación integral turístico de la isla de el hierro. definición del modelo y plan de acción. Unpublished manuscript. 
Actas del Seminario Internacional Destinos Turísticos Inteligentes:

nuevos horizontes en la investigación y gestión del turismo

Universidad de Alicante, 26 y 27 de octubre de 2017

Secretaría de Estado de Telecomunicaciones y para la Sociedad de la Información. Ministerio de Industria, Turismo y Comercio. Estrategia 2011-2015. Plan Avanza 2. 2011. Retrieved from: https://www.planavanza.es/InformacionGeneral/ Estrategia2011/Documents/Estrategia_2011-2015_PA2.pdf

SEGITTUR (2013). Retrieved December 02, 2014 from http://www.segittur.es/ opencms/export/sites/segitur/.content/galerias/descargas/documentos/Presentacin-Destinos-Tursticos-Inteligentes.pdf

SMILEGOV, Multilevel Governance (2013). Enhancing effective implementation of sustainable energy action plans in European islands through reinforcement of smart multilevel governance. Islands Strategy Paper. Version 15/10/2013. Retrieved November 25, 2014 from http://www.sustainableislands.eu/BlockImages/InLibraryData/GalleryData/Islands\%20strategy\%20communication\%20 paper.pdf

Sofronijević, A., Milićević, V., \& Ilić, B. (2014). Smart City as Framework for Creating Competitive Advantages in International Business Management. Management, 71. Retrieved December 12, 2014 from http://www.management.fon.rs/management/e_management_71_english_01.pdf

Schaffers, H., Komninos, N., Pallot, M., Trousse, B., Nilsson, M., \& Oliveira, A. (2011). Smart cities and the future internet: Towards cooperation frameworks for open innovation Springer.

Stamboulis, Y., \& Skayannis, P. (2003). Innovation strategies and technology for experience-based tourism. Tourism Management, 24(1), 35-43.

Timón, D. A. B. (2004). El concepto de destino turístico. una aproximación geográfico-territorial. Estudios Turísticos, 160

Tomás Casado, F. (2011). Ciudades inteligentes. Retrieved from http://es.slideshare. net/ftomas/ciudades-inteligentes?related $=2$

Vanolo, A. (2013). Smartmentality: The smart city as disciplinary strategy. Urban Studies, 1-16. doi:10.1177/0042098013494427

Vicini, S., Bellini, S., \& Sanna, A. (2012). How to co-create Internet of things-enabled services for smarter cities. Stuttgart: IARIA

Wang, D., Li, X. R., \& Li, Y. (2013). China's «smart tourism destination» initiative: A taste of the service-dominant logic. Journal of Destination Marketing \& Management, 2(2), 59-61.

Yacuzzi, E. (2005, El estudio de caso como metodología de investigación: Teoría, mecanismos causales, validación. Econstor,, 1.

Zheng Xiang and lis Tussyadiah. 2014. Information and Communication Technologies in Tourism 2014: Proceedings of the International Conference in Dublin, Ireland, January 21-24, 2014. Springer Publishing Company, Incorporated 
Actas del Seminario Internacional Destinos Turísticos Inteligentes:

nuevos horizontes en la investigación y gestión del turismo

Universidad de Alicante, 26 y 27 de octubre de 2017

Zygiaris, S. (2013). Smart city reference model: Assisting planners to conceptualize the building of smart city innovation ecosystems. Journal of the Knowledge Economy, 4(2), 217-231. 